\title{
NOTES
}

\section{"BE RADICAL-BE RADICAL-BE NOT TOO DAMNED RADICAL!": THE ORIGINS AND RESONANCE OF WHITMAN'S SIGNATURE EXPRESSION}

Near the end of his life Walt Whitman advised Horace Traubel to "be radical—be radical—be not too damned radical!"' As early as 1930 Vernon Parrington's Main Currents in American Thought identified this remark as a key to Whitman's character and outlook. Many others have agreed. Thomas Brasher sees the statement as evidence that Whitman's "radicalness, cockiness, and boldness" were often tempered by a "prudent, sensible side." David Reynolds cites the "not too damned radical" statement as giving voice to a conservative element in the poet's temperament. Jon Panish notes that the phrase illustrates the complexity of Whitman's political attitudes. ${ }^{2}$ Recently, the quotation has gained currency beyond the sphere of literary criticism. Bryan Garman singles out the phrase by titling the introduction to his book on the workingclass hero "Be radical-be not too damned radical." And Paul Berman invokes the phrase yet again in an essay reflecting on how the U.S. should react to Muslim militants. ${ }^{3}$

If Whitman was fond of a paradoxically prudent radicalism, he was even more fond of the rhetorical pattern "Be . . be . . . be not" through which he expressed it. He habitually put forth two assertions followed by a negation cutting against the grain of emphasis. For example, he told Traubel to "be cocky, be cocky, don't be too damned cocky!" (WWWC, 2:135-136); "be individualistic, be individualistic, be not too damned individualistic" (WWWC, 3:122); and "be bold, be bold, bè not too damned bold!" (WWWC, 5:381). Brasher, in first pointing out Whitman's fondness for this construction, failed to observe that the "be bold, be bold, be not too damned bold" phrasing directly echoes Edmund Spenser, Whitman's likely source for the pattern underlying all these varying expressions. In the third book of The Faerie Qveene, the Knight Britomart enters the House of Busirane so as to rescue Amoret, Scudamour's abducted bride. Britomart has entered a torturer's castle (the walls are decorated with tapestries depicting Jove's rape of assorted mortal women):

Tho as she backward cast her busie eye,

To search each secrete of that goodly sted,

Ouer the dore thus written she did spye

Be bold: she oft and oft it ouer-red,

Yet could not find what sence it figured:

But what so were therein, or writ or ment,

She was no whit thereby discouraged,

From prosecuting of her first intent, 
But forward with bold steps into the next roome went.

$\ldots$

And as she lookt about, she did behold,

How ouer that same dore was likewise writ,

$B e$ bolde, be bolde, and euery where Be bold,

That much she muz'd, yet could not construe it

By any riddling skill, or commune wit.

At last she spyde at that rowmes vpper end,

Another yron dore, on which was writ,

$B e$ not too bold; whereto though she did bend

Her earnest mind, yet wist not what it might intend. ${ }^{4}$

In short, what has been understood as a signature Whitman expression became his through adoption and modification rather than through individual invention. ${ }^{5}$ Ironically, when Whitman borrowed from Spenser he relied on a writer who in turn probably borrowed either from Ovid's myth of Venus and Adonis in Metamorphoses or from a folktale. ${ }^{6}$

Whitman toyed with different articulations of the "be . . be . . . be not" rhetorical pattern. For example, he once gave Traubel advice about writing: "you are on the right track-; you will get somewhere. I don't seem to have any advice to give, except perhaps this: Be natural, be natural, be natural! $\mathrm{Be}$ a damned fool, be wise if you must (can't help it), be anything-; only be natural!" (WWWC, 1:194). Apparently, it is possible to be too radical or individualistic or cocky or bold, but not too natural. Yet the very "be . . be . . ." pattern sets Whitman's mind on the course of assertion and counter assertion, so, in this instance, he embeds within his reflections on being natural the oscillation between being foolish and wise. Whitman's firm belief in the middle way, in finding a mean between extremes, is Aristotelian. As Whitman once wrote in a note to himself: "Aristotle mediums between extremes, also experimental philosophy. (It seems to be the substratum on which are based modern literature, education, and very largely modern character.)"?

In another remarkable exchange with Traubel, Whitman discusses a belief in immortality and says: "perhaps the truth is, we are not so sure we are sure - not any of us - it is our age, in which the tendency of belief is, not to be so damned certain we are certain." He goes on to talk about John Burroughs's scientific temperament - "he will not say he is sure." Then Whitman says, "This spirit - the not-too-damned sure spirit-is the glory of our age" (WWWC, 6:146-147). The whole "be . . . be . . . be not too damned" pattern seems to have become for Whitman a conscious syntax of his own thinking and, though its origins were much earlier, a defining marker of his era. ${ }^{8}$

University of Nebraska - Lincoln

KenNeth M. Price

\section{NOTES}

1 Horace Traubel, With Walt Whitman in Camden, 9 vols. (vol. 1: Boston: Small Maynard, 1906; vol. 2: New York: D. Appleton, 1908; vol. 3: New York: Mitchell Kennerley, 1914; vol. 4., ed. Sculley Bradley, Philadelphia: University of Pennsylvania Press, 1953; vol. 5, ed. Gertrude Traubel, Carbondale: Southern Illinois Univer- 
sity Press, 1964; vol. 6, ed. Gertrude Traubel, Carbondale: Southern Illinois University Press, 1982; vol. 7, ed. Jeanne Chapman and Robert MacIsaac, Carbondale: Southern Illinois University Press, 1992; vols. 8 and 9, ed. Jeanne Chapman and Robert MacIsaac, Oregon House, CA: W.L. Bentley, 1996), 1:223. Hereafter cited as WWWC.

2 Vernon Louis Parrington, in the posthumously published third volume of Main Currents in American Thought, entitled The Beginnings of Critical Realism in America (New York: Harcourt, Brace, 1930), 85; see Brasher, "'Be-, Be-, Be not too Damned-," Walt Whitman Review, 14 (June 1968), 60; David Reynolds, "Politics and Poetry: Whitman's Leaves of Grass and the Social Crisis of the 1850s," The Cambridge Companion to Walt Whitman, ed. Ezra Greenspan (New York: Cambridge University Press, 1995), 82; Jon Panish, "Radicalism," Walt Whitman: An Encyclopedia, ed. J. R. LeMaster and Donald D. Kummings (New York: Garland, 1998) writes: "While Whitman's ideas on many of these issues put him among those people who were categorized at the time as 'radical,' his identity as a political and social radical is actually complex, as Whitman himself indicated when he told Horace Traubel, ' $\mathrm{Be}$ radical - be radical — be not too damned radical!'” (570).

3 Bryan K. Garman, A Race of Singers: Whitman's Working-Class Hero from Guthrie to Springsteen (Chapel Hill: University of North Carolina Press, 2000), 1. Paul Berman, "Totalitarianism and the Role of Intellectuals," Chronicle of Higher Education, May 9, 2003, http://209.157.64.200/focus/f-news/1048757/posts. Accessed March 1, 2004.

4 Edmund Spenser, The Faerie Qveene, ed. A. C. Hamilton et al. (Harlow, England: Pearson, 2001), 3.11.50, 54. Floyd Stovall has written that "it is inconceivable that [Whitman ] could have endured to read much of the Faerie Queene" (The Foreground of Leaves of Grass [Charlottesville: University Press of Virginia, 1974], 234). Stovall is probably correct, though there is evidence that Whitman at least read a selection from Spenser in Dr. L[udwig] Herrig's The British Classical Authors. Select Specimens of the National Literature of England from G. Chaucer to the Present Time. Poetry and Prose (Brunswick: George Westermann, 1851). In fact, Whitman read Spenser's "The Legend of the Knight of the Red Cross" carefully enough to correct a typographical error (see Kenneth M. Price, "Whitman's Anthology of English Literature," [Duke University] Library Notes 50 [January 1982], 33). Whitman's interest in Spenser may also have been piqued by his reading of Emerson, who quoted the "be not too bold" passage at the end of an essay on "Plato; or, the Philosopher."

Curiously, though, Whitman's first known encounter with the "be . . . be . . be be not too bold" passage came from an unlikely source: his reading of an April 1849 review of "Tennyson's Poems" in Blackwood's Magazine that discusses two Tennyson volumes, one entitled Poems and the other The Princess: A Medley. Whitman heavily annotated many parts of the article, though he did not happen to mark this passage: "The young poet had been spoilt-had grown over-confident. He was like Spenser's Knight in the Palace of Love, who sees written over every door, 'Be bold! Be bold!' Only over one door does [s] he read the salutary caution, 'Be not too bold!'” (457). Whitman's clipped copy of this review is in the Trent Collection, Perkins Library, Duke University.

5 It is as if someone were to say: We hold these truths - we damn well better-to be self evident: that all men and women are created equal. When we modify famous statements in the course of conversation, we often do not cite sources.

6 "Bee bold on cowards (Venus sayd) for whoso dooth advaunce / Himselfe against the bold, may hap too meete with sum mischaunce. / Wherfore I pray thee my sweete boy forbeare too bold to bee." Ovid's Metamorphoses 10:628-630, as quoted in Iris Tillman Hill, "Britomart and Be Bold, Be not too Bold," ELH 38 (1971), 174. 
Regarding the folk tale Dorothy Stephens remarks: "Signs in the House of Busyrane caution Britomart, 'Be bold, be bold,' and then 'Be not too bold' (III.xi.54), quotations from the Bluebeard folk tale. In the Bluebeard text behind Spenser's text, the next sentence of the jingle is 'Lest that your heart's blood should run cold.' Because in the folk tale Mr. Fox (Bluebeard) commands Lady Mary not to look at his former wives, intending to make her join them if she does, Busyrane's own allusion to the tale implicitly warns his headstrong guest that it could be lethal for her to attempt any sort of meeting with the woman who is his prisoner." See Stephens, The Limits of Eroticism in Post-Petrarchan Narrative (Cambridge: Cambridge University Press, 1998), 32. Shakespeare also alluded to this tale in Much Ado About Nothing. For further analysis of this folk tradition, see K. M. Briggs's discussion of "The Hole the Fox Did Make," an offshoot of the international tale type The Robber Bridegroom in "Historical Traditions in English Folk-Tales," Folklore 75 (1964), 235-240. Briggs prints one of the more memorable versions of this tale, centrally relying on the "be . . . be . . be not too bold" pattern in A Dictionary of British Folk-Tales in the English Language (London: Routledge \& Kegan Paul, 1970), 1:446-448. For further contextual discussion, see Jacqueline Simpson, “'Be Bold, but not Too Bold': Female Courage in Some British and Scandinavian Legends," Folklore 102 (1991), 19-20.

7 Whitman, Notebooks and Unpublished Prose Manuscripts, ed. Edward Grier (New York: New York University Press, 1984), 5:1884. Ed Folsom discusses this passage in "Trying to do Fair: Walt Whitman and the Good Life," Speakeasy 10 (March/April 2004), 17.

8 Thanks go to Ed Folsom for drawing my attention to this passage and for his comments on it.

\section{AN UNRECORDED WHITMAN INTERVIEW}

In the New York Tribune of May 19, 1890, there appeared an article entitled "Whitman Near the End," in which an anonymous correspondent reports on his trip to Whitman's Mickle Street home in Camden, New Jersey, where he talked with Mary Davis, Whitman's housekeeper, as well as with Whitman himself. The article is accompanied by an engraved portrait of Whitman, an engraving of his Mickle Street home, and a facsimile of his signature. A copy of the article was tucked into one of the copies of the 1881-1882 Leaves of Grass (Boston: James R. Osgood) owned by Whitman collector Kendall Reed. Previously unrecorded, this interview offers some illuminating details of Whitman's last years, including an intriguing explanation of why he never married. Here is the entire article:

\section{WHITMAN NEAR THE END}

Pitiful Life of the Good Gray Poet at Camden 